Audiology

Neurotology
Audiol Neurotol 2011;16:347-358

DOI: $\underline{10.1159 / 000322851}$
Received: May 20, 2010

Accepted after revision: November 10, 2010

Published online: December 30, 2010

\title{
Infection-Mediated Vasoactive Peptides Modulate Cochlear Uptake of Fluorescent Gentamicin
}

\author{
Ja-Won Koo ${ }^{\mathrm{a}-\mathrm{c}}$ Qi Wang $^{\mathrm{a}}$ Peter S. Steyger ${ }^{\mathrm{a}}$ \\ ${ }^{a}$ Oregon Hearing Research Center, Oregon Health \& Science University, Portland, Oreg., USA; ${ }^{b}$ Department of \\ Otorhinolaryngology - Head and Neck Surgery, Seoul National University Bundang Hospital, Seongnam, and \\ 'Research Center for Sensory Organs, Medical Research Center, Seoul National University, Seoul, South Korea
}

\section{Key Words}

Ototoxicity - Aminoglycosides - Gentamicin - Histamine •

Serotonin $\cdot$ Blood-labyrinth barrier

\begin{abstract}
Inflammatory mediators released during bacterial infection include vasoactive peptides such as histamine and serotonin, and their serum levels are frequently elevated. These peptides also modulate the vascular permeability of endothelial cells lining the blood-brain and blood-labyrinth barriers (BLB). These peptides may also modulate the permeability of the BLB to ototoxic aminoglycoside antibiotics prescribed to resolve bacterial sepsis. To test this hypothesis, we compared the effect of histamine and serotonin on the cochlear distribution of fluorescently conjugated gentamicin (GTTR) in control animals at $0.5,1$ and $3 \mathrm{~h}$ after injection of GTTR. The intensity of GTTR fluorescence was attenuated at $1 \mathrm{~h}$ in the histamine group compared to control mice, and more intense $3 \mathrm{~h}$ after injection $(\mathrm{p}<0.05)$. In the serotonin group, the intensity of GTTR fluorescence was attenuated at 0.5 and $1 \mathrm{~h}(\mathrm{p}<0.05)$ and was increased at $3 \mathrm{~h}$ compared to control animals, where GTTR intensities peaked at $1 \mathrm{~h}$ and then plateaued or was slightly decreased at $3 \mathrm{~h}$. This biphasic pattern of modulation was statistically significant in the api-
\end{abstract}

cal turn of the cochlea. No difference in the intensity of GTTR fluorescence was observed in kidney proximal tubules. Systemic increases in serum levels of vasoactive peptides can modulate cochlear uptake of gentamicin, likely via permeability changes in the BLB. Conditions that influence serum levels of vasoactive peptides may potentiate aminoglycoside ototoxicity.

Copyright $\odot 2010$ S. Karger AG, Basel

\section{Introduction}

Aminoglycoside ototoxicity is a complex process that typically involves sensory hair cell cytotoxicity in the cochlea and vestibular labyrinth, as well as differing cellular uptake kinetics and susceptibility. Additional factors further predispose patients to enhanced ototoxicity, including aging, concomitant use of other ototoxic drugs (e.g. loop diuretics), noise exposure, preexisting hearing, balance or renal dysfunction, and individual genetic susceptibility [Govaerts et al., 1990; Triggs and Charles, 1999; Selimoglu, 2007]. Although the severity and extent of aminoglycoside ototoxicity are influenced by these factors, ototoxicity usually occurs in a dose-dependent manner [Forge and Schacht, 2000].

\section{KARGER}

๑) 2010 S. Karger AG, Basel

Fax +4161306 1234 E-Mail karger@karger.ch www.karger.com www.karger.com/aud
Peter S. Steyger, $\mathrm{PhD}$

Oregon Hearing Research Center, NRC04

Oregon Health \& Science University

3181 Southwest Sam Jackson Park Road, Portland, OR 97239 (USA)

Tel. +1 503494 1062, Fax +1 503494 5656, E-Mail steygerp@ ohsu.edu 
The mechanisms by which systemically administered aminoglycosides enter the cochlear fluids and tissues are not clearly understood. A series of studies suggest that cochlear hair cells primarily take up aminoglycosides across their apical membranes, i.e. from endolymph in vivo [Hashino and Shero, 1995; Marcotti et al., 2005; Dai et al., 2006; Dai and Steyger, 2008]. Indirect evidence suggests that systemic aminoglycosides are trafficked from the strial capillaries across the stria vascularis into endolymph [Dai and Steyger, 2008; Wang and Steyger, 2009]. Strial trafficking of aminoglycosides appears to be regulated at the strial endothelial cell membranes and at the marginal cell-intermediate/endothelial cell boundary [Wang and Steyger, 2009], which together constitute functional barriers of the cochlea (blood-labyrinth barrier, $\mathrm{BLB})$, and is similar to the blood-brain barrier (BBB) that separates the central nervous system and cerebrospinal fluid from the systemic vasculature.

These specialized barrier structures also protect the inner ear and brain from systemic immune responses since even a limited inflammatory response and scar formation in lesions within these barriers induce functional deterioration in the associated neural systems [Barker and Billingham, 1977; Mogi et al., 1982; Harris, 1983]. However, the permeability of the BLB and BBB (which are formed by tight junctions between adjacent vascular endothelial cells), can be altered by vasoactive substances such as bradykinin [Butt, 1995; Sarker et al., 2000], serotonin [Sharma and Dey, 1986a, b; Markowitz et al., 1987; Sarkar and Fraser, 1996], histamine [Schilling and Wahl, 1994; Sarker et al., 1998] and nucleotides [Olesen and Crone, 1986]. Such vasoactive substances are modulated during bacterial infection and are responsible for the generation of systemic symptoms such as fever, chilling, headache, swelling and hypotension. In a rat model of pneumococcal infection, histamine levels in serum and hypothalamus increased over time after inoculation of type I pneumococci, in parallel with the increasing severity of symptoms [Popenenkova and Romanovskaia, 1968]. Serum levels of histamine are also increased in patients with bacterial sepsis [Neugebauer et al., 1996]. In combination, these findings suggest that alteration in the permeability of the $\mathrm{BBB}$ during serious bacterial infection is mediated by a series of infection-induced vasoactive peptides such as histamine. In the inner ear, the permeability of the BLB is modulated by histamine when given simultaneously with prostaglandin $\mathrm{E}_{2}$. The amount of a tracer trimethylphenylammonium in perilymph increases over time and in a dose-dependent manner [Inamura and Salt, 1992].
Endotoxemia increases plasma extravasation by changing local microvascular permeability, or by disrupting the endothelial integrity of the BBB [SchmidSchönbein, 1993; Abbott, 2000]. Endothelial damage and increased permeability can also be mediated by serotonin receptors, and the process inhibited by the serotonin receptor antagonist methysergide [Makabali et al., 1983; Walther et al., 2001]. Elevated serum levels of serotonin also increase the permeability of the pial venular capillaries (in the innermost layer of the meningeal membranes surrounding the brain and spinal cord) to Lucifer Yellow, and this is blocked by the serotonin receptor antagonist LY53857 [Sarkar and Fraser, 1996]. Serotonin also induces significant extravasation of plasma proteins from dural vessels, the basilar, anterior inferior cerebellar and spiral modiolar arteries, and increased tracer permeability within the stria vascularis and spiral limbus in the cochlea [Markowitz et al., 1987; Vass et al., 2001; Koo and Balaban, 2006]. These observations imply that vasoactive peptides modulated during bacterial infection could affect $\mathrm{BBB}$ and BLB permeability, and, if so, increase the risk of ototoxicity during aminoglycoside treatment with detrimental consequences for audiological function during recovery.

We hypothesize that the vasoactive peptides histamine and serotonin alter BLB permeability and modulate aminoglycoside uptake by cochlear tissues and hair cells. After administration of either vasoactive peptide, we observed attenuated fluorescent gentamicin (GTTR) uptake at 0.5 and $1 \mathrm{~h}$, and increased uptake $3 \mathrm{~h}$ after GTTR injection compared to control animals.

\section{Materials and Methods}

\section{Preparation of GTTR Conjugate}

Gentamicin sulfate $(200 \mathrm{mg} / \mathrm{ml}$ in $0.1 \mathrm{M}$ potassium bicarbonate, $\mathrm{pH}$ 10) and succinimidyl esters of Texas Red (Invitrogen, Carlsbad, Calif., USA; $10 \mathrm{mg} / \mathrm{ml}$ in dimethyl formamide) were agitated together for several days at $4^{\circ} \mathrm{C}$. A high molar ratio of free gentamicin to Texas Red esters ensures that only 1 Texas Red molecule is conjugated to any individual gentamicin molecule [Sandoval et al., 1998]. We used reversed-phase chromatography, using C18 columns (Burdick and Jackson, Muskegon, Mich., USA) to purify the conjugate from unconjugated gentamicin and contamination by unreacted Texas Red [Myrdal et al., 2005].

\section{Experimental Groups}

C57BL/6 mice (15-25 g; 4-7 weeks old) with normal Preyer's reflex were used. The control group received an intravenous (i.v.) injection of phosphate-buffered saline $(100 \mu \mathrm{l} / 10 \mathrm{~g})$ via the tail vein immediately followed by an intraperitoneal (i.p.) injection of $2 \mathrm{mg} / \mathrm{kg}$ GTTR (see table 1 for animal numbers/group, and figure 
1 for the experimental protocol). The histamine group received an i.v. injection of $10^{-5} \mathrm{M}$ of histamine $(100 \mu \mathrm{l} / 10 \mathrm{~g})$ solution immediately followed by an i.p. injection of $2 \mathrm{mg} / \mathrm{kg}$ GTTR. The serotonin group received an i.v. injection of $10^{-6} \mathrm{M}$ of serotonin (100 $\mu \mathrm{l} / 10 \mathrm{~g}$ ) solution immediately followed by an i.p. injection of $2 \mathrm{mg} / \mathrm{kg}$ GTTR. To determine if unconjugated Texas Red was taken up in the cochlear tissue and renal cortex, and also if its uptake was modulated by histamine and serotonin, the mice received an i.v. injection of either vasoactive peptide, followed by an i.p. injection of the molar equivalent of Texas Red, and were euthanized at 0.5 or $1 \mathrm{~h}$. The doses of histamine and serotonin were chosen since they had been effective concentrations in modulating the permeability of the BBB in the previous literature and were within a tolerable range [Markowitz et al., 1987; Laroche et al., 1991; Pollock et al., 1991].

\section{Murine Tissue Preparation}

At specified time points $(30,60,180 \mathrm{~min})$ after GTTR injection, mice were anesthetized and venous blood collected prior to transcardiac perfusion with saline, then $4 \%$ paraformaldehyde for fixation. Following fixation, the bony labyrinth and kidney were obtained and postfixed for $15 \mathrm{~min}$. The lateral wall was excised, and cochlear coils containing the organ of Corti isolated and whole-mounted. Sections of kidney were cut on a vibratome to a thickness of $100 \mu \mathrm{m}$. Prepared tissues were permeabilized with fixative containing $0.5 \%$ Triton X-100 for $45 \mathrm{~min}$, rinsed, labeled with Alexa-488-conjugated phalloidin to localize filamentous actin, and postfixed with $4 \%$ paraformaldehyde for $15 \mathrm{~min}$ [Dai et al., 2006].

\section{Cell Culture}

Mouse kidney cell lines were generated as described previously [Turker et al., 1999]. Briefly, mouse kidney was minced, digested with Liberase Blendzyme (Roche Diagnostics Corp.) at $37^{\circ} \mathrm{C}$ for $45 \mathrm{~min}$, and spun down. Cells were resuspended in DMEM supplemented with $15 \%$ FBS, and plated in $100-\mathrm{mm}$ plates. Primary cultures were maintained in DMEM with 15\% FBS, and clones expanded to identify cells that had undergone spontaneous immortalization. Two kidney proximal and a distal tubule cell line were identified based on morphology, separated and maintained in DMEM with 10\% FBS. A proximal tubule cell line (KPT2) was used in this experiment [Karasawa et al., 2008].

\section{Imaging}

Tissues from the most apical half-turn of the cochlea and a quarter turn of the basal coil adjacent to the hook region were mounted on slides, immersed in Vectashield (Vector Laboratories, Calif., USA), cover slipped and examined using a Bio-Rad MRC 1024 ES laser scanning confocal system attached to a Nikon Eclipse TE300 inverted microscope. Alexa-488 and Texas Red images were collected sequentially using a $1024 \times 1024$ pixel box size and a $\times 60$ lens (numerical aperture: 1.4). All specimens from the cochlea of the red channel were imaged at the same laser intensity and gain settings, including control tissues [Wang and Steyger, 2009]. Laser settings were adjusted for imaging kidney sections.

\section{Image Analysis}

Focal planes representing the marginal cell layer, intrastrial tissues (consisting of intrastrial space, intermediate and endothe-

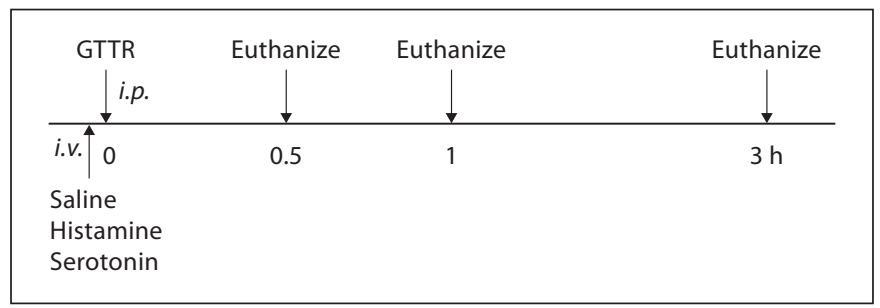

Fig. 1. Experimental protocol. Following i.v. injection of histamine or serotonin, GTTR is injected intraperitoneally (i.p.). Control mice received an i.v. injection of saline instead of vasoactive peptides. Mice were sacrificed at 0.5, 1 and $3 \mathrm{~h}$ after GTTR injection.

Table 1. Number of animals per condition and time point

\begin{tabular}{llrl}
\hline & $0.5 \mathrm{~h}$ & $1 \mathrm{~h}$ & $3 \mathrm{~h}$ \\
\hline Saline + GTTR & 8 & 13 & 8 \\
Histamine + GTTR & 5 & 9 & 6 \\
Serotonin + GTTR & 6 & 9 & 6 \\
\hline
\end{tabular}

lial cells) and basal cell layer were localized by Alexa-488-conjugated phalloidin-labeled (green) images obtained during sequential imaging. Images of each region of interest (ROI) from the red channel were manually segmented for pixel intensity determination (ImageJ). To normalize data between experimental sets, the mean intensity was ratioed against the control specimen (intensity at 1-hour time point for control animal, at each ROI) and plotted. The Mann-Whitney U test was used to test for the difference in the relative fluorescence intensity of GTTR between control and experimental groups at each time point and each ROI.

\section{Serum Kinetics}

The level of the gentamicin epitope of GTTR in serum samples collected at each time point was tested by the particle-enhanced turbidimetric inhibition immunoassay [Newman et al., 1992] by OHSU Diagnostic Services.

\section{Results}

\section{Serum Kinetics}

Serum levels of GTTR peaked at $1 \mathrm{~h}$ with an average concentration ( \pm standard error of the mean, SEM) of $3.58( \pm 0.29) \mu \mathrm{l} / \mathrm{ml}$ in the control group, and $3.43( \pm 0.56)$ $\mu \mathrm{l} / \mathrm{ml}$ in the histamine group, and decreased slightly at the 3-hour time point. In the serotonin group, serum levels of GTTR reached an average concentration of 3.65 $( \pm 0.32) \mu \mathrm{l} / \mathrm{ml}$ at $1 \mathrm{~h}$ and then plateaued. The serum concentration of GTTR at $1 \mathrm{~h}$ in the control group was sig- 
nificantly higher than at $0.5 \mathrm{~h}(\mathrm{p}<0.05)$. The serotonin and histamine groups showed higher averaged serum concentrations at the 1-hour time point, but this did not reach statistical significance $(\mathrm{p}=0.095$ and 0.10 , respectively) (fig. 2). Serum concentrations of GTTR at each time point did not differ significantly with or without treatment with vasoactive peptides $(p>0.05)$.

\section{Cochlear Uptake of GTTR in Control Mice}

Quantitative image analysis of GTTR fluorescence was conducted on the whole-mounted stria vascularis and organ of Corti at individual time points after GTTR injection. GTTR fluorescence in each ROI (marginal cells, intrastrial tissues, basal cells and outer hair cells, $\mathrm{OHC}$ ) peaked at $1 \mathrm{~h}$ and was maintained at that level up to $3 \mathrm{~h}$ after injection (fig 3 ). The fluorescence intensity of strial cells in the basal turn was statistically significantly higher than that of the apical turn after $1 \mathrm{~h}(\mathrm{p}<0.001)$ and $3 \mathrm{~h}(\mathrm{p}<0.05)$. However, no significant difference in GTTR fluorescence intensity was observed in $\mathrm{OHC}$ from apical and basal coils at the same time points (data not shown).

\section{Cochlear Uptake of GTTR after Histamine}

\section{Administration}

In mice treated with histamine, GTTR fluorescence in strial cells increased over time up to $3 \mathrm{~h}$ after GTTR injection (fig. 4, 5). Compared to control cochleae, where GTTR fluorescence peaked at $1 \mathrm{~h}$ after GTTR injection, in animals treated with histamine, GTTR fluorescence in strial cells was attenuated at the 1-hour time point and displayed enhanced fluorescence at the 3-hour time point. This pattern of modulation following systemic injection of histamine was consistently observed and statistically significant in the apical turn $(\mathrm{p}<0.05)$ (fig. 5). In the basal turn, GTTR fluorescence in OHC was significantly increased $3 \mathrm{~h}$ after GTTR injection without statistically significant attenuation of fluorescence in $\mathrm{OHC}$ at the 0.5 - and 1-hour time points compared to control mice.

\section{Cochlear Uptake of GTTR after Serotonin}

\section{Administration}

In mice treated with serotonin, GTTR fluorescence in the stria vascularis continued to increase over time (up to $3 \mathrm{~h}$ ) after GTTR injection, compared to control cochleae, where the uptake of GTTR peaked $1 \mathrm{~h}$ after GTTR injection (fig. 6, 7). GTTR fluorescence in mice treated with serotonin was significantly attenuated at 0.5 and $1 \mathrm{~h}$ after injection compared to control mice, particu-

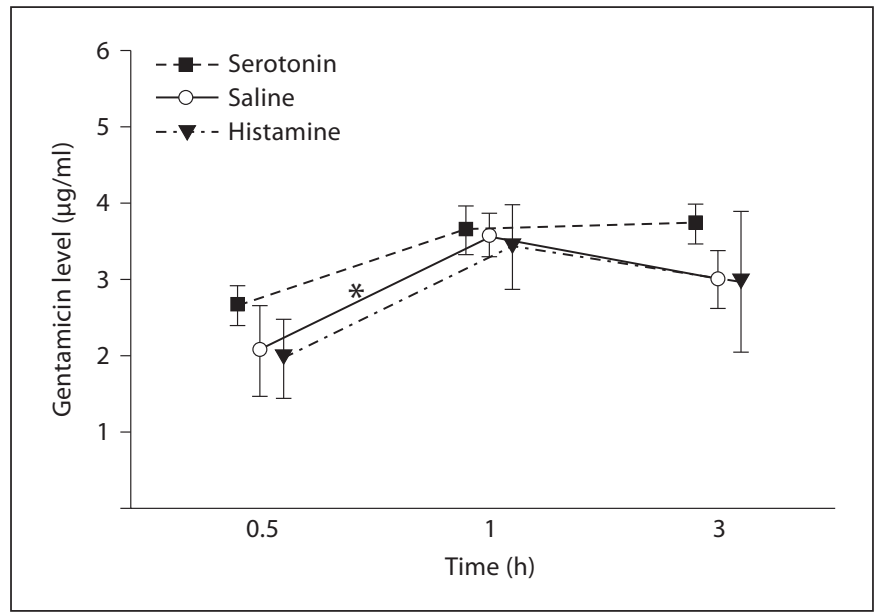

Fig. 2. GTTR serum kinetics were not affected by vasoactive peptides. Serum levels of GTTR ( $2 \mathrm{mg} / \mathrm{kg}$, i.p.) at each time point were plotted. The averaged value peaked at $1 \mathrm{~h}$ and then plateaued or was slightly decreased at $3 \mathrm{~h}$ after injection. Serum GTTR levels at $1 \mathrm{~h}$ in the control group were statistically significantly higher than at $0.5 \mathrm{~h}$. The serotonin and histamine groups also showed higher averaged GTTR serum concentrations at $1 \mathrm{~h}$ (compared to $0.5 \mathrm{~h}$ ), but this did not reach statistical significance ( $\mathrm{p}=0.095$ and 0.1 , respectively). The serum concentrations of GTTR did not differ between groups at each time point $(p>0.05) .{ }^{*} p<0.05$. Error bars $=$ SEM.

larly in the apical turn $(\mathrm{p}<0.05)$ (fig. 7). However, GTTR uptake continued to increase and was greater in the strial tissues of serotonin-treated mice compared to control mice $3 \mathrm{~h}$ after injection, although in most cases this did not reach statistical significance (fig. 7). The modulation of GTTR uptake by serotonin was not significant in $\mathrm{OHC}$.

\section{GTTR Uptake in the Renal Proximal Tubules}

GTTR fluorescence was mostly restricted to brush border microvilli and punctate fluorescence in the apical cytoplasm $0.5 \mathrm{~h}$ after GTTR injection. This pattern of GTTR fluorescence was augmented at $1 \mathrm{~h}$, with diffuse cytoplasmic fluorescence within proximal tubule cells (fig. 8). The cytoplasmic fluorescence in proximal tubule cells continued to increase over time up to $3 \mathrm{~h}$ in both control and experimental groups (fig. 6, 8). At each time point, the intensity was similar in all 3 treatment groups (fig. 8). Quantitation of cytoplasmic fluorescence intensity revealed no significant differences between the 3 groups (fig. 8). 

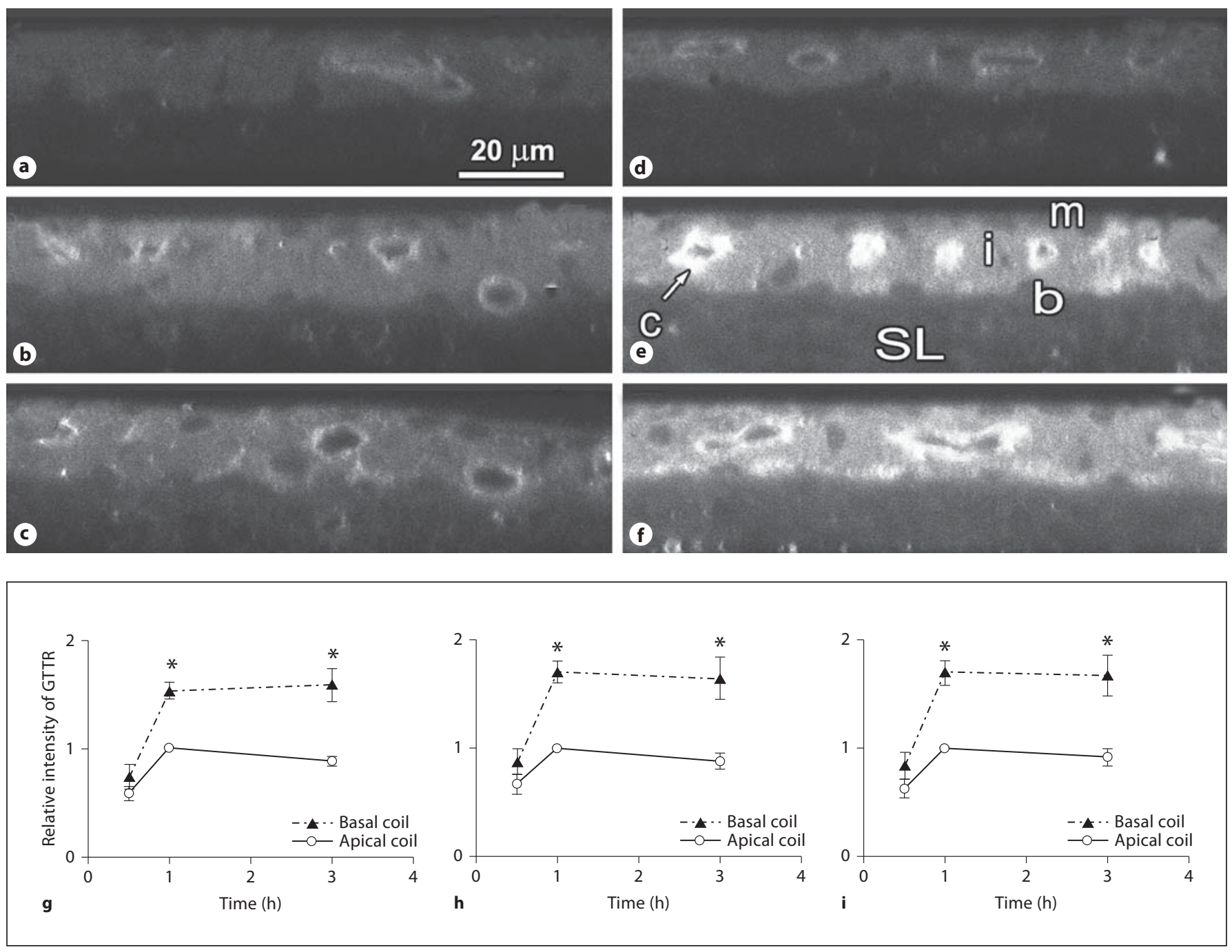

Fig. 3. Apicobasal comparison of strial GTTR fluorescence over time in control mice. Control mice received an i.v. injection of saline $(10 \mathrm{ml} / \mathrm{kg})$ followed by an i.p. injection of GTTR $(2 \mathrm{mg} / \mathrm{kg})$. The confocal $x z$ planes of the cochlear lateral wall showed more intense fluorescence at the basal turn at $1 \mathrm{~h} \mathrm{(e)} \mathrm{and} 3 \mathrm{~h}(\mathbf{f})$ after GTTR injection compared to the apical turn at the same time points (b, c). Note the intense capillary wall fluorescence (c; arrow) in intrastrial tissues (i), and the higher GTTR fluorescence in the stria vascularis, demarcated by the marginal (m) and basal cell layers (b) in the basal turn at $1 \mathrm{~h} \mathrm{(e);} \mathrm{compared} \mathrm{to} \mathrm{the} \mathrm{spiral}$ ligament (SL). The intense GTTR fluorescence in the capillary endothelium (e) became weaker over time. GTTR florescence at $1 \mathrm{~h}$ was stronger than at $0.5 \mathrm{~h}$ in both apical (a) and basal (b) cochlear coils. The fluorescence intensity in the $x y$ planes in each ROI was normalized by ratioing the GTTR intensity at each time point against the intensity in the same ROI at the 1-hour time point in control mice, and then plotted. The relative GTTR fluorescence was averaged and compared between apical and basal turns of marginal cells $(\mathbf{g})$, intrastrial tissues $(\mathbf{h})$ and basal cells (i). ${ }^{*} \mathrm{p}<$ 0.05 .
Unconjugated Texas Red Uptake following Histamine or Serotonin Administration

Texas Red fluorescence was negligible in cochlear tissues and kidney proximal tubules after $0.5 \mathrm{~h}$ (data not shown) or $1 \mathrm{~h}$ (fig. 9a, e) following injection of unconjugated Texas Red. Tissue uptake of unconjugated Texas
Red was not facilitated by systemic treatment with serotonin (fig. 9b, f) or histamine (fig. 9c, g), while GTTR fluorescence was observed in marginal cells (fig. 9d) and renal proximal tubules (fig. $9 \mathrm{~h}$ ) $1 \mathrm{~h}$ after mice had received an i.v. injection of saline followed by an i.p. injection of GTTR. 

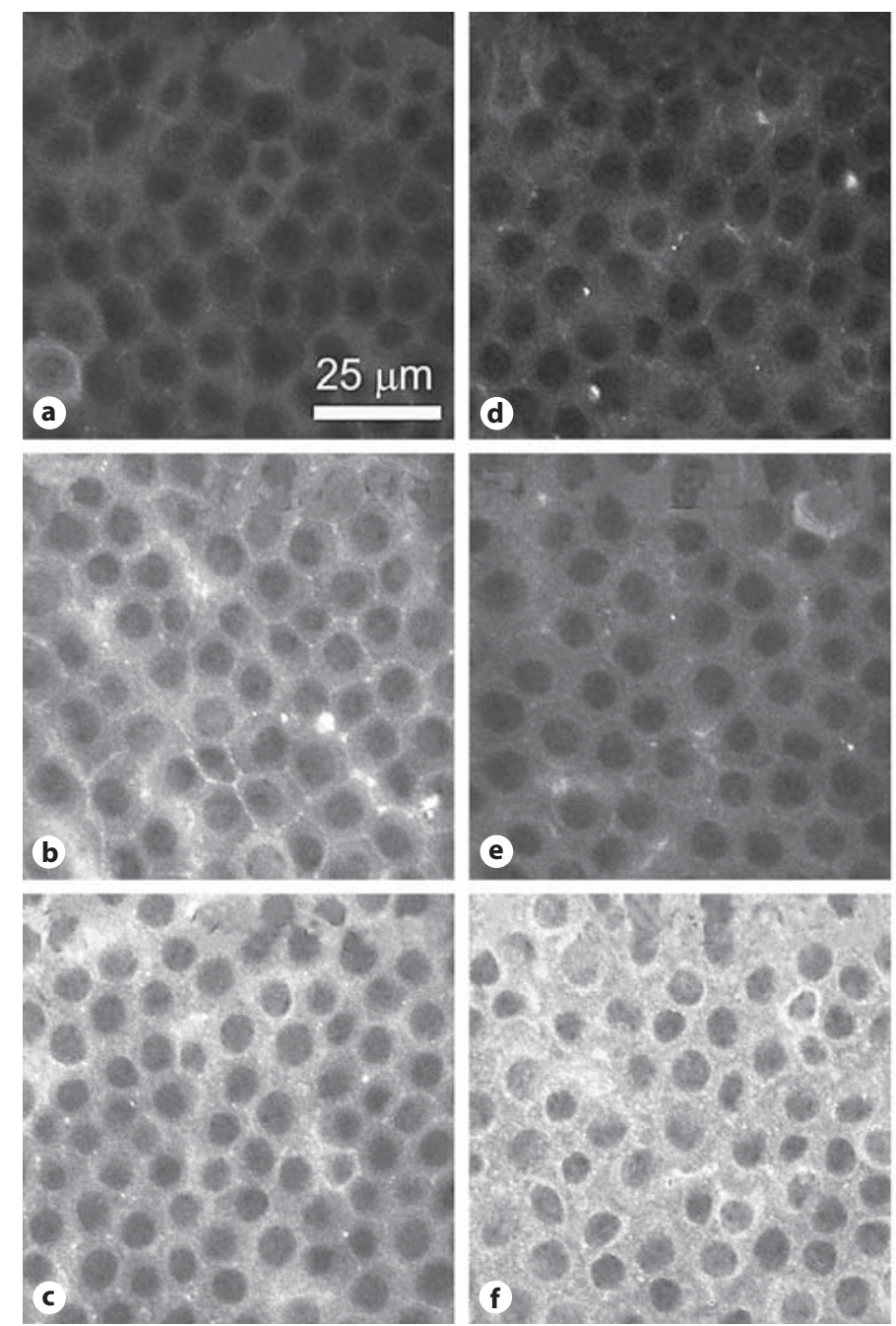

Fig. 4. GTTR uptake in marginal cells (a-f) and basal OHC (g-I) after histamine injection. Mice received an i.v. injection of histamine $\left(\mathbf{d}-\mathbf{f}, \mathbf{j}-\mathbf{I} ; 10^{-5} \mathrm{M}\right)$ or saline $(\mathbf{a}-\mathbf{c}, \mathbf{g}-\mathbf{i})$ followed by an i.p. injection of GTTR $(2 \mathrm{mg} / \mathrm{kg})$. At $0.5 \mathrm{~h}$, the GTTR fluorescence was similar in control (a) and histamine-treated (d) marginal cells After $1 \mathrm{~h}$, GTTR fluorescence was attenuated in histamine-treated marginal cells (e) compared to control marginal cells (b). After
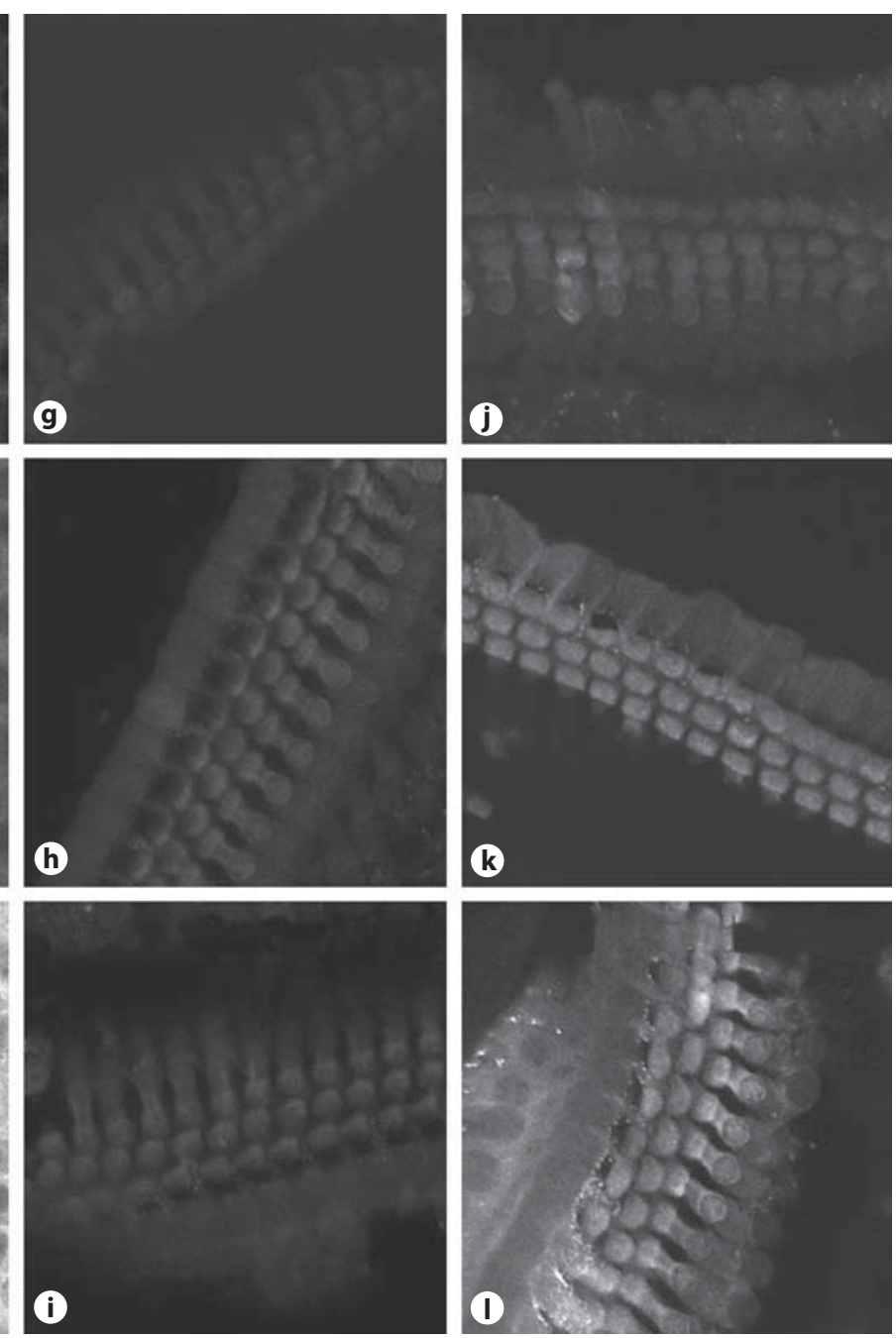

$3 \mathrm{~h}$, GTTR fluorescence was more intense in histamine-treated marginal cells (f) than in control marginal cells (c). In the organ of Corti from the basal turn of the cochlea, OHC uptake of GTTR was somewhat similar in control and histamine-treated animals at $0.5(\mathbf{g}, \mathbf{j})$ and $1 \mathrm{~h}(\mathbf{h}, \mathbf{k})$. After $3 \mathrm{~h}$, OHC GTTR fluorescence in histamine-treated animals (I) was more intense than in control animals (i).

\section{Effects of Histamine and Serotonin on GTTR Uptake} in Cultured Proximal Tubular Cells

Cultured proximal tubule cells were pretreated with a dose range of histamine $\left(10^{-6} \mathrm{M}, 10^{-5} \mathrm{M}, 10^{-4} \mathrm{M}\right)$ or serotonin $\left(10^{-7} \mathrm{M}, 10^{-6} \mathrm{M}, 10^{-5} \mathrm{M}\right)$ for 2 or $15 \mathrm{~min}$, prior to treatment with $5 \mu \mathrm{g} / \mathrm{ml}$ GTTR for $30 \mathrm{~s}$, washing and fixation. Treatment with histamine or serotonin did not significantly change GTTR fluorescence in murine proximal tubule cells in vitro (data not shown).

\section{Discussion}

The present study demonstrates that strial uptake of fluorescent gentamicin is modulated by elevated serum levels of histamine and serotonin in mice, while such modulation is not present in renal proximal tubules. The strial uptake of GTTR was initially attenuated by systemic administration of serotonin, while strial uptake of GTTR was enhanced $3 \mathrm{~h}$ after injection of histamine. These phe- 


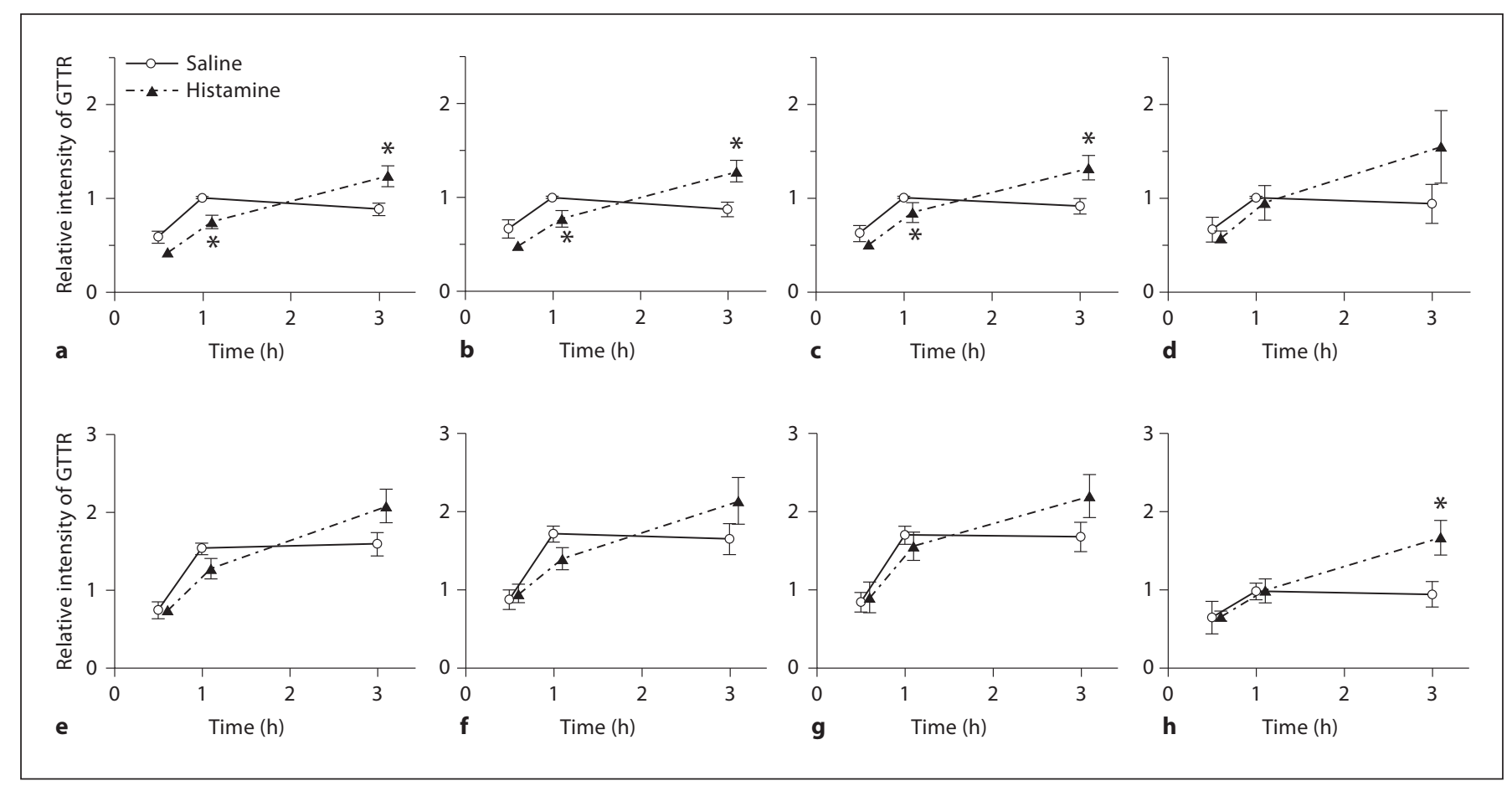

Fig. 5. Histamine modulates cochlear uptake of GTTR. The intensity of GTTR fluorescence in each cell type in the stria vascularis and $\mathrm{OHC}$ of histamine-treated animals was compared with that in control animals. In control cochleae, GTTR uptake peaked at $1 \mathrm{~h}$ after injection; in histamine-treated animals, GTTR uptake was initially attenuated at $1 \mathrm{~h}$ after injection, and continued to increase up to the 3-hour time point. GTTR fluorescence in marginal cells $(\mathbf{a}, \mathbf{e})$, intrastrial tissues $(\mathbf{b}, \mathbf{f})$ and basal cells $(\mathbf{c}, \mathbf{g})$ showed attenuated uptake at $1 \mathrm{~h}$ and relatively more intense florescence at $3 \mathrm{~h}$ in histamine-treated animals compared to control animals. This was especially significant in apical cochlear turns (a-c; * p < 0.05). In OHCs, attenuation of GTTR fluorescence at $1 \mathrm{~h}$ in histamine-treated animals was not statistically different (d, h), but after $3 \mathrm{~h}$, the increased uptake in $\mathrm{OHC}$ was statistically significant, especially in basal cochlear coils (h; $\left.{ }^{*} \mathrm{p}<0.05\right)$. Error bars = SEM. a-d Apical coil. e-h Basal coil. nomena suggest that entry of gentamicin into the inner ear is regulated at the level of capillary endothelium constituting the $\mathrm{BLB}$, and that cochlear uptake of gentamicin can be affected by several clinical conditions which elevate serum levels of endogenous vasoactive peptides.

\section{Serum Kinetics}

In this study, serum levels of the gentamicin epitope of GTTR peaked at $1 \mathrm{~h}$ after injection and decreased gradually. In a previous study, serum levels of GTTR peaked at $3 \mathrm{~h}$ before falling, with a half-life of $130 \mathrm{~min}$ [Wang and Steyger, 2009]. In this study, control animals had received an i.v. injection of saline $(10 \mathrm{ml} / \mathrm{kg})$ solution prior to injection of GTTR, hydrating the animals. Hydration influences the pharmacodynamics of ototoxic agents [Vogelzang, 1991; Obatomi and Plummer, 1993], and is likely responsible for the faster serum kinetics of GTTR in this study. Pretreatment with systemic injections of hista- mine or serotonin did not significantly affect serum concentrations of GTTR compared to the hydrated control animals in this study.

\section{GTTR Uptake in the Stria Vascularis and Kidney of Hydrated Animals}

Without hydration (i.e. pretreatment with saline), GTTR uptake by strial tissues also peaked at $3 \mathrm{~h}$, following GTTR serum kinetics [Wang and Steyger, 2009]. In this study, GTTR fluorescence in strial cells peaked at $1 \mathrm{~h}$ and slightly declined $3 \mathrm{~h}$ after GTTR injection, following GTTR serum kinetics in hydrated animals (fig. 2). In contrast to the parallel changes between GTTR levels in the stria vascularis and serum, GTTR uptake by renal proximal tubule cells increased over time (up to $3 \mathrm{~h}$ ) and did not correspond to serum GTTR levels. Furthermore, GTTR uptake by proximal tubule cells was not affected by systemic administration of histamine and serotonin. 

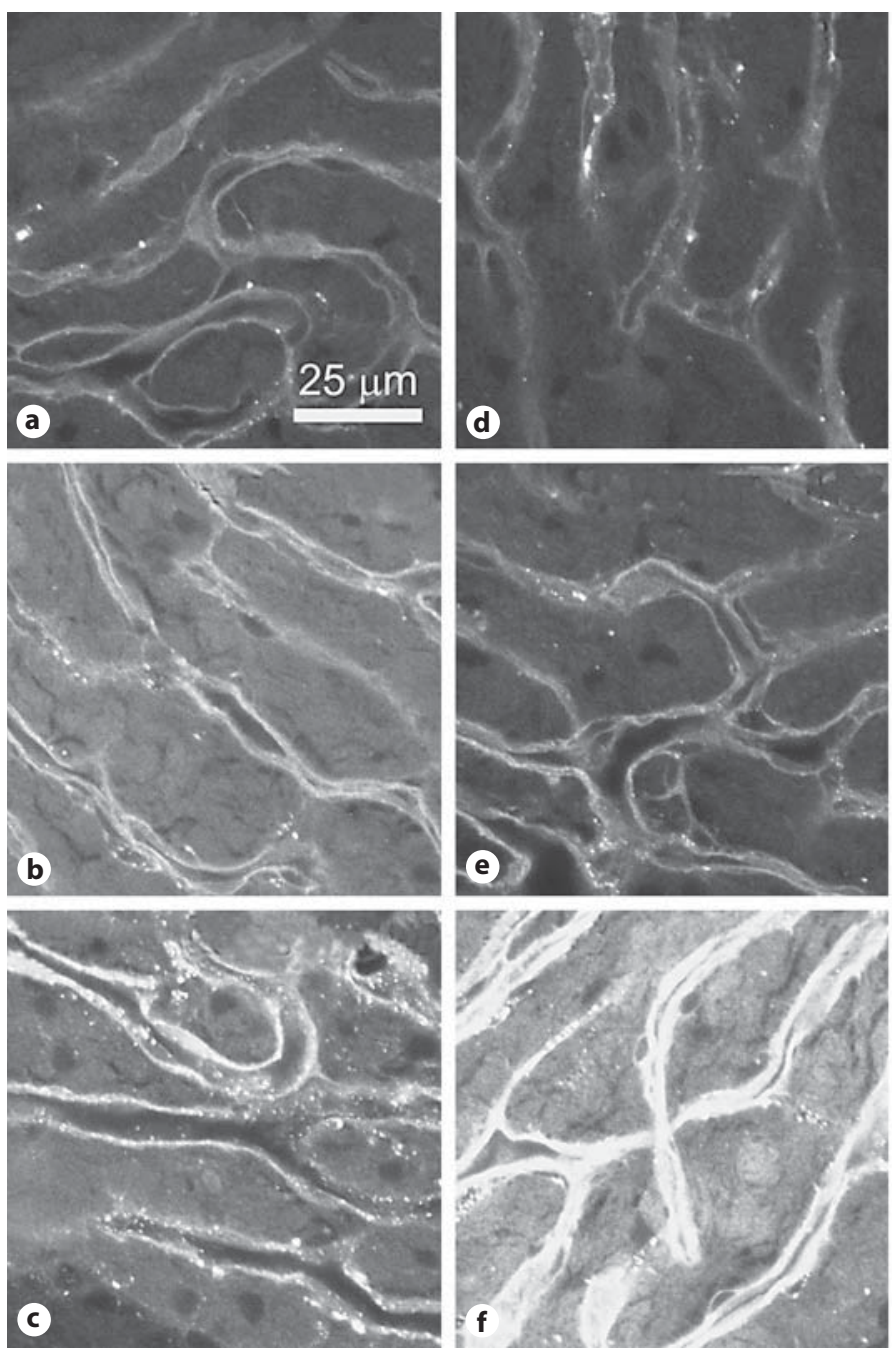

Fig. 6. GTTR uptake in intrastrial tissues (a-f) and renal cortex $(\mathbf{g}-\mathbf{I})$ after serotonin injection. Mice received an i.v. injection of serotonin $\left(\mathbf{d}-\mathbf{f}, \mathbf{j}-\mathbf{l} ; 10^{-6} \mathrm{M}\right)$ or saline $(\mathbf{a}-\mathbf{c}, \mathbf{g}-\mathbf{i})$ followed by an i.p. injection of GTTR $(2 \mathrm{mg} / \mathrm{kg})$. GTTR fluorescence in intrastrial tissues was attenuated in serotonin-treated (d) animals compared to controls (a) at $0.5 \mathrm{~h}$. After $1 \mathrm{~h}$, attenuation of GTTR fluorescence in intrastrial tissues was persistent in serotonin-treated animals (e) compared to control animals (b). However, intrastrial GTTR fluo-
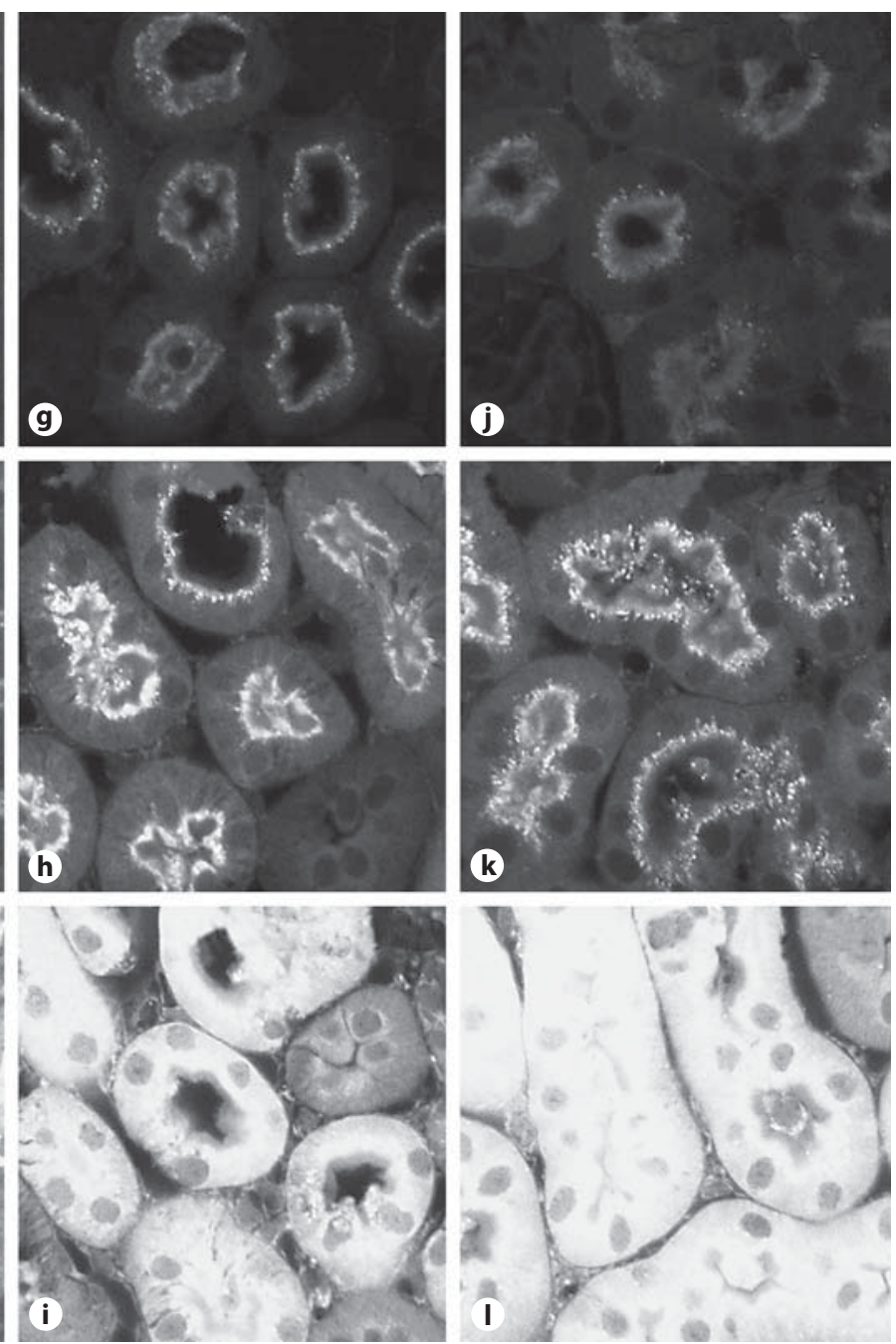

rescence in serotonin-treated animals (f) was more intense than in control animals (c) after $3 \mathrm{~h}$. In the renal cortex of control mice, GTTR fluorescence was limited to the brush border epithelium of renal proximal tubules $30 \mathrm{~min}$ after GTTR injection $(\mathbf{g})$. Cytoplasmic GTTR fluorescence began to appear after $1 \mathrm{~h}(\mathbf{h})$ and continued to increase over time up to the 3 -hour time point (i). GTTR fluorescence in serotonin-treated animals $(\mathbf{j}-\mathbf{I})$ was similar to that in control animals at these time points.

Since renal capillary fenestration allows free passage of GTTR, the degree of proximal tubule cell uptake is likely dependent on mechanisms of GTTR uptake by proximal tubule cells that are unresponsive to the vasoactive mechanisms of histamine and serotonin in vivo or in vitro.

\section{Effect of Histamine or Serotonin on the BLB}

GTTR fluorescence in apical strial tissues exposed to systemically administered serotonin was significantly at- tenuated at 0.5 and $1 \mathrm{~h}$ after GTTR injection compared to control mice ( $p<0.05)$. GTTR uptake continued to increase and was greater in the strial tissues of serotonintreated mice compared to control mice $3 \mathrm{~h}$ after injection, although most results did not reach statistical significance (fig. 7).

In the histamine group, GTTR fluorescence in apical strial tissues was similar to that in control mice at $30 \mathrm{~min}$. However, after $1 \mathrm{~h}$, GTTR fluorescence in strial apical tis- 


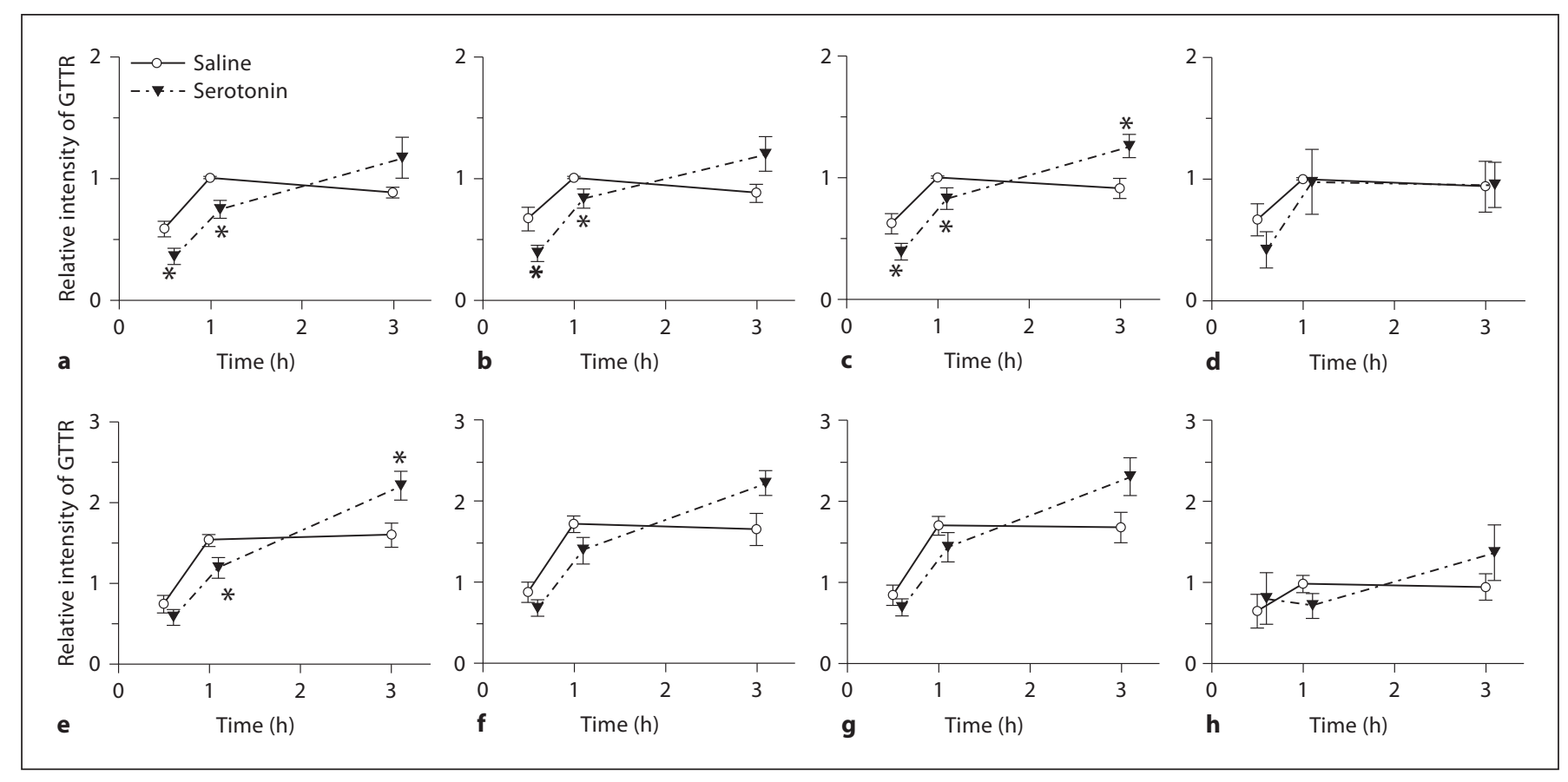

Fig. 7. Serotonin modulated cochlear uptake of GTTR. The intensity of GTTR fluorescence in each cell type in the stria vascularis and $\mathrm{OHC}$ of serotonin-treated animals were compared with control animals. In control cochleae, GTTR uptake peaked at $1 \mathrm{~h}$ after injection. In serotonin-treated animals, GTTR fluorescence in marginal cells (a, e), intrastrial tissues $(\mathbf{b}, \mathbf{f})$ and basal cells $(\mathbf{c}, \mathbf{g})$ showed attenuated uptake at 0.5 and $1 \mathrm{~h}$ compared to control animals, especially in the apical turn $\left(\mathbf{a}-\mathbf{c} ;{ }^{*} \mathrm{p}<0.05\right)$. GTTR uptake was greater in the strial tissues of serotonin-treated mice than in control mice $3 \mathrm{~h}$ after injection, although this did not reach statistical significance except for the basal cell layer of the apical turn (c) and the marginal cell layer of the basal turn (e). Similar modulation also occurred in $\mathrm{OHC}$, but this was not statistically significant over time $(\mathbf{d}, \mathbf{h})$. Error bars = SEM. a-d Apical coil. e-h Basal coil. sues was significantly attenuated compared to the control group, where GTTR fluorescence peaked at $1 \mathrm{~h}$ and then plateaued or was slightly decreased at $3 \mathrm{~h}$. In contrast, in the histamine group, GTTR fluorescence was greater than in control mice $3 \mathrm{~h}$ after injection, especially in apical strial tissues $(\mathrm{p}<0.05)$. The plasma half-life of vasoactive peptides is very short ( $1 \mathrm{~min}$ for serotonin, $4 \mathrm{~min}$ for histamine). Thus, the mechanisms of how systemic injection of these vasoactive peptides can modulate BLB permeability to GTTR 3 h later remain uncertain. Vasoactive peptides are also dispersed into the extravascular space, and this may mediate a prolonged effect [Kownatzki, 1984]. Vasoactive peptides may also trigger an intracellular endothelial mechanism that has a prolonged influence on the permeability of the BLB. The effect of histamine on cochlear blood flow and the cochlear lateral wall has been investigated previously. Systemic infusion of $\beta$-histine, a histamine analogue, increases cochlear blood flow and reduces systemic blood pressure [Laurikainen et

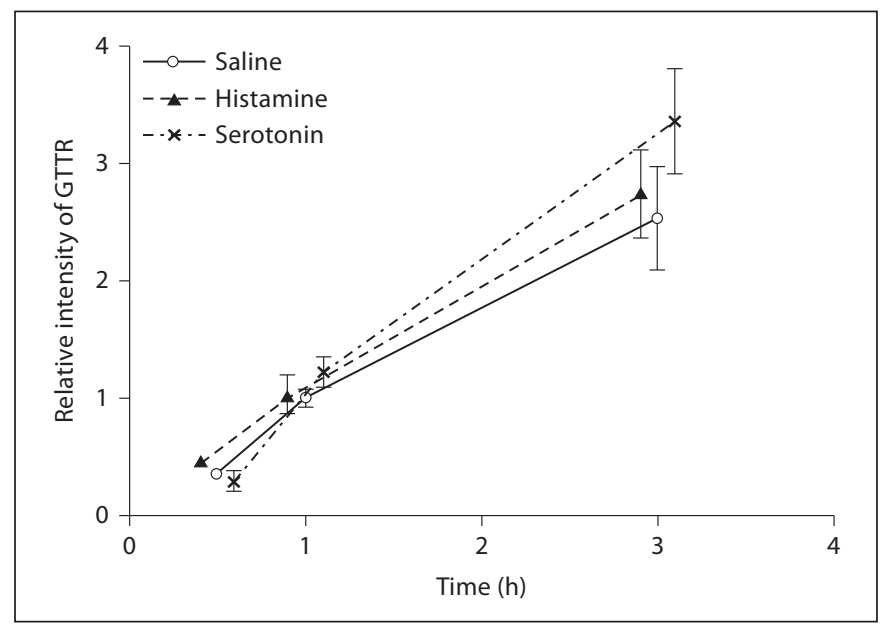

Fig. 8. GTTR uptake in proximal tubules was not affected by histamine and serotonin. The intensity of GTTR fluorescence in proximal tubules increased over time to $3 \mathrm{~h}$. This time-dependent increase was not affected by vasoactive peptides. Error bars = SEM. 
9
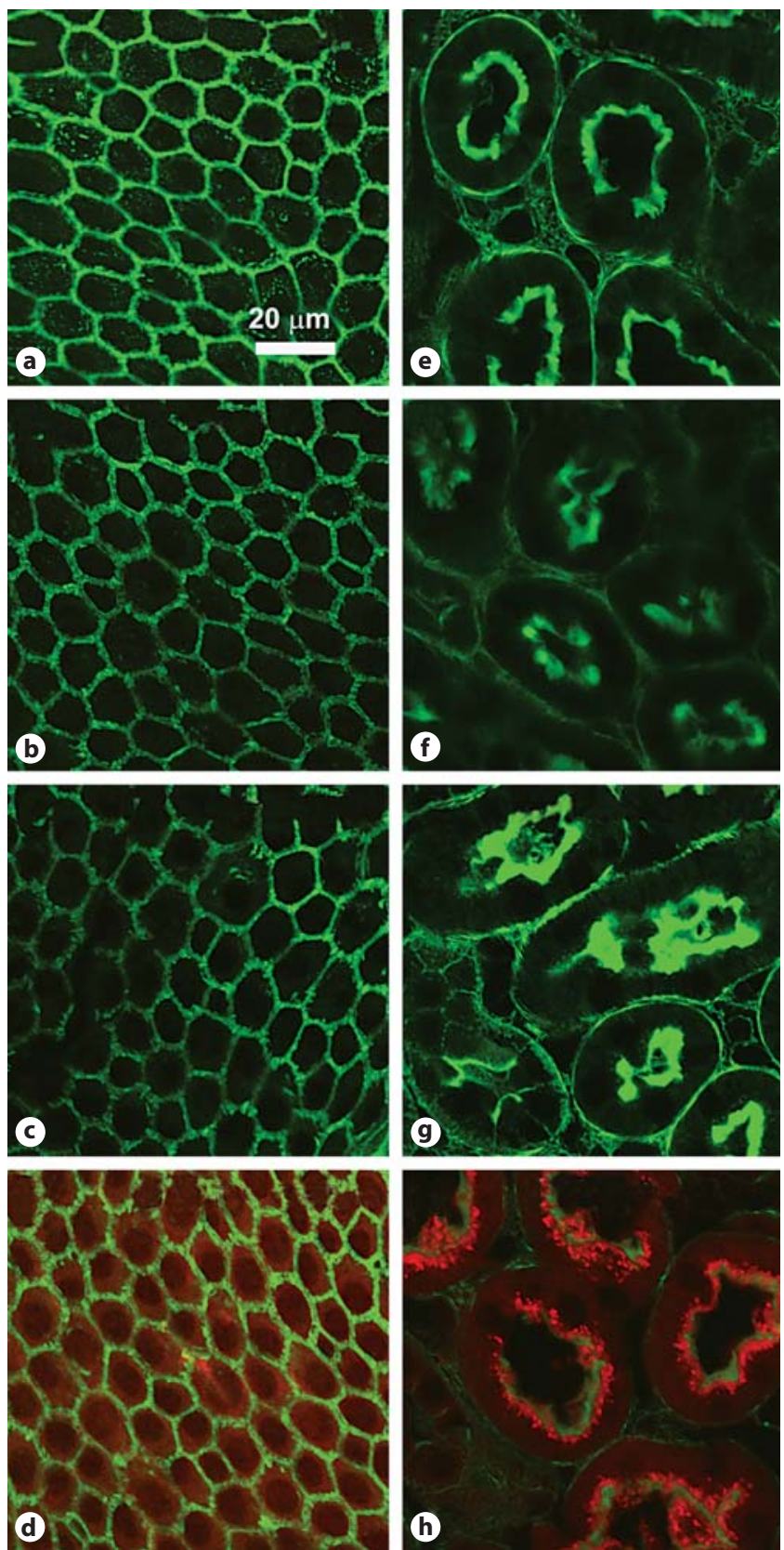

Fig. 9. Unconjugated Texas Red was not taken up by strial or renal tissues, regardless of vasoactive peptide administration. Mice received an i.v. injection of saline $(\mathbf{a}, \mathbf{e})$, serotonin $\left(\mathbf{b}, \mathbf{f} ; 10^{-6} \mathrm{M}\right)$ or histamine $\left(\mathbf{c}, \mathbf{g} ; 10^{-5} \mathrm{M}\right)$ followed by an i.p. injection of unconjugated Texas Red. There was no Texas Red fluorescence (red) in marginal cells $(\mathbf{a}-\mathbf{d})$ or renal proximal tubule cells $(\mathbf{e}-\mathbf{h})$ when
10
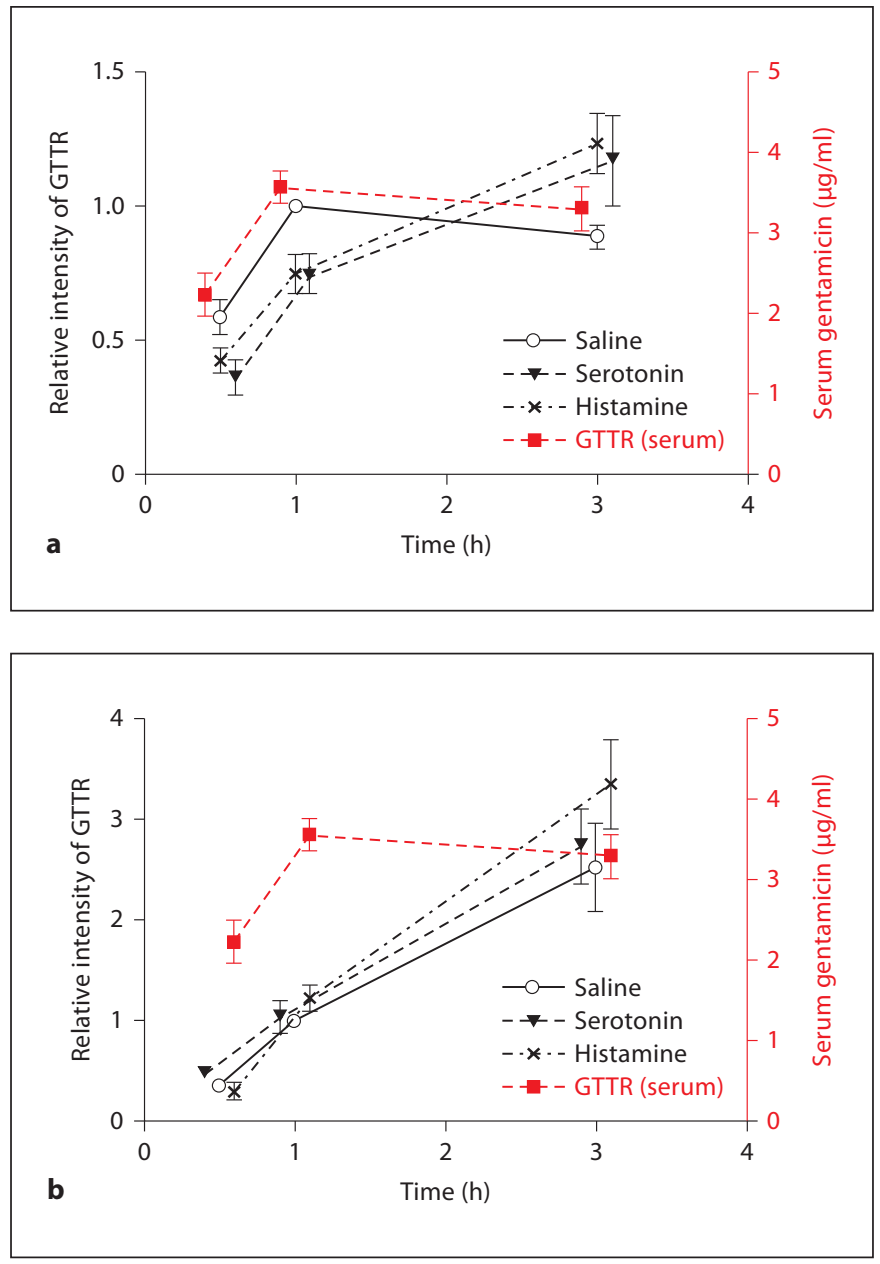

Texas Red was given with saline (a, e) at $1 \mathrm{~h}$. Serotonin $(\mathbf{b}, \mathbf{f})$ or histamine $(\mathbf{c}, \mathbf{g})$ injections did not facilitate the uptake of unconjugated Texas Red into marginal cells or proximal tubule cells at $1 \mathrm{~h}$. Note that GTTR fluorescence (red) was observed in marginal cells (d) and renal proximal tubules (h) of mice having received an intravenous injection of saline followed by an intraperitoneal injection of GTTR $(2 \mathrm{mg} / \mathrm{kg})$ at the same time point.

Fig. 10. Histamine and serotonin modulated cochlear, but nor kidney, uptake of GTTR. Serum GTTR levels, and the relative fluorescence intensity of GTTR in marginal cells (a) and proximal tubules (b). a Serum and marginal cell levels of GTTR in control mice (saline) began decreasing after $1 \mathrm{~h}$ (indicating clearance), while marginal cell uptake of GTTR in serotoninand histamine-treated animals continued to increase for up to $3 \mathrm{~h}$. b Fluorescence intensity of GTTR in proximal tubules continued to increase for up to $3 \mathrm{~h}$ regardless of serotonin and histamine treatment. 
al., 1998]. The rate of vascular permeability was increased in a time- and dose-dependent manner, especially for small protein tracers such as horseradish peroxidase [Duvall et al., 1979]. Although histamine primarily increases the vascular permeability of strial capillaries, and was expected to elevate GTTR uptake, systemic hemodynamic changes may temporarily attenuate strial GTTR uptake, and this was restored following stabilization. Alternatively, the delayed accentuation of GTTR uptake in the experimental groups may represent a rebound effect following cessation of a vasoactive peptide inhibitory effect that attenuates strial uptake of GTTR. Further investigation using continuous infusion may clarify these observations if consistent attenuation of GTTR uptake occurs following histamine administration.

In figure 10, the cytoplasmic intensity curves for GTTR fluorescence in marginal and proximal tubule cells are overlaid with the serum concentration of GTTR. Although serum and strial levels of GTTR in control mice (saline) decreased after $1 \mathrm{~h}$ (indicating clearance), strial uptake of GTTR in the serotonin and histamine groups continued to increase (fig. 10a). Likewise, renal proximal tubule cells also showed a continuing increase in GTTR fluorescence for up to $3 \mathrm{~h}$ after injection (fig. 10b), and histamine and serotonin had no significant effect on proximal tubule cell uptake of GTTR in vivo or in vitro.
Thus, histamine and serotonin have a biphasic influence on GTTR uptake by strial tissues, with initial attenuation followed by accentuated uptake compared to control tissues. These experiments used single-bolus injection of vasoactive peptides that initially attenuated GTTR uptake. However, in the clinical setting with patients experiencing bacterial sepsis, the serum levels of these vasoactive peptides are thought to be chronically increased [Popenenkova and Romanovskaia, 1968; Neugebauer et al., 1996]. If so, sustained elevated serum levels of these vasoactive peptides may provide partial protection against the ototoxic effects of aminoglycosides until the inflammatory response declines. A decline in the serum levels of these vasoactive peptides may increase the trafficking of aminoglycosides across the BLB, with consequential increased vulnerability of inner ear structures to ototoxic drugs. This hypothesis and potential consequences are currently investigated.

\section{Acknowledgments}

Funded by grants DC 04555 (P.S.S.) and P30 DC 05983 from the National Institute of Deafness and Other Communication Disorders, National Institutes of Health, and by Seoul National University Bundang Hospital grant 02-2008-019 (J.-W.K.).

\section{References}

Abbott NJ: Inflammatory mediators and modulation of blood-brain barrier permeability. Cell Mol Neurobiol 2000;20:131-147.

-Barker CF, Billingham RE: Immunologically privileged sites. Adv Immunol 1977;25:1-54.

Butt AM: Effect of inflammatory agents on electrical resistance across the blood-brain barrier in pial microvessels of anaesthetized rats. Brain Res 1995;696:145-150.

Dai CF, Mangiardi D, Cotanche DA, Steyger PS: Uptake of fluorescent gentamicin by vertebrate sensory cells in vivo. Hear Res 2006; 213:64-78.

Dai CF, Steyger PS: A systemic gentamicin pathway across the stria vascularis. Hear Res 2008;235:114-124.

Duvall AJ 3rd, Hukee MJ, Santi PA: The morphologic effects of histamine on the lateral cochlear wall. Otolaryngol Head Neck Surg 1979;87:666-684.

Forge A, Schacht J: Aminoglycoside antibiotics. Audiol Neurootol 2000;5:3-22.
- Govaerts PJ, Claes J, van de Heyning PH, Jorens PG, Marquet J, de Broe ME: Aminoglycoside-induced ototoxicity. Toxicol Lett 1990; 52:227-251.

Harris JP: Immunology of the inner ear: re sponse of the inner ear to antigen challenge. Otolaryngol Head Neck Surg 1983;91:18-32.

Hashino E, Shero M: Endocytosis of aminoglycoside antibiotics in sensory hair cells. Brain Res 1995;704:135-140.

-Inamura N, Salt AN: Permeability changes of the blood-labyrinth barrier measured in vivo during experimental treatments. Hear Res 1992;61:12-18.

Karasawa T, Wang Q, David L, Steyger PS: Identification of gentamicin-binding proteins in the inner ear. ARO Midwinter Meet Abstr 2008;31:725.

Koo JW, Balaban CD: Serotonin-induced plasma extravasation in the murine inner ear: possible mechanism of migraine-associated inner ear dysfunction. Cephalalgia 2006;26: $1310-1319$
Kownatzki E: Clearance of histamine from the peritoneal cavity of rats. Agents Actions 1984;15:249-253.

Laroche D, Vergnaud MC, Sillard B, Soufarapis $\mathrm{H}$, Bricard $\mathrm{H}$ : Biochemical markers of anaphylactoid reactions to drugs: comparison of plasma histamine and tryptase. Anesthesiology 1991;75:945-949.

Laurikainen E, Miller JM, Nuttall AL, Quirk WS: The vascular mechanism of action of betahistine in the inner ear of the guinea pig. Eur Arch Otorhinolaryngol 1998;255:119123.

Makabali GL, Mandal AK, Morris JA: An assessment of the participatory role of prostaglandins and serotonin in the pathophysiology of endotoxic shock. Am J Obstet Gynecol 1983; 145:439-445.

-Marcotti W, van Netten SM, Kros CJ: The aminoglycoside antibiotic dihydrostreptomycin rapidly enters mouse outer hair cells through the mechano-electrical transducer channels. J Physiol 2005;567:505-521. 
Markowitz S, Saito K, Moskowitz MA: Neurogenically mediated leakage of plasma protein occurs from blood vessels in dura mater but not brain. J Neurosci 1987;7:4129-4136.

Mogi G, Lim DJ, Watanabe N: Immunologic study on the inner ear: immunoglobulins in perilymph. Arch Otolaryngol 1982;108:270275.

Myrdal SE, Johnson KC, Steyger PS: Cytoplasmic and intra-nuclear binding of gentamicin does not require endocytosis. Hear Res 2005; 204:156-169.

-Neugebauer E, Lorenz W, Rixen D, Stinner B, Sauer S, Dietz W: Histamine release in sepsis: a prospective, controlled, clinical study. Crit Care Med 1996;24:1670-1677.

-Newman DJ, Henneberry H, Price CP: Particle enhanced light scattering immunoassay. Ann Clin Biochem 1992;29(pt 1):22-42.

Obatomi DK, Plummer DT: Influence of hydration states on the acute nephrotoxic effect of gentamicin in the rat. Toxicology 1993;80: 141-152.

-Olesen SP, Crone C: Substances that rapidly augment ionic conductance of endothelium in cerebral venules. Acta Physiol Scand 1986; 127:233-241.

-Pollock I, Murdoch RD, Lessof MH: Plasma histamine and clinical tolerance to infused histamine in normal, atopic and urticarial subjects. Agents Actions 1991;32:359-365.
Popenenkova ZA, Romanovskaia MG: Changes in the concentration of histamine in the blood and organs of rats with experimental pneumococcal infections (in Russian). Biull Eksp Biol Med 1968;65:43-45.

Sandoval R, Leiser J, Molitoris BA: Aminoglycoside antibiotics traffic to the Golgi complex in LLC-PK1 cells. J Am Soc Nephrol 1998;9: 167-174.

Sarkar FH, Fraser PA: Effect of 5-HT in the regulation of cerebral microvascular permeability in the anaesthetized rat. J Physiol 1996; 491:29P-30P.

Sarker MH, Easton AS, Fraser PA: Regulation of cerebral microvascular permeability by histamine in the anaesthetized rat. J Physiol 1998;507(pt 3):909-918.

-Sarker MH, Hu DE, Fraser PA: Acute effects of bradykinin on cerebral microvascular permeability in the anaesthetized rat. J Physiol 2000;528(pt 1):177-187.

Schilling L, Wahl M: Opening of the blood-brain barrier during cortical superfusion with histamine. Brain Res 1994;653:289-296.

Schmid-Schönbein GW: The damaging potential of leukocyte activation in the microcirculation. Angiology 1993;44:45-56.

Selimoglu E: Aminoglycoside-induced ototoxicity. Curr Pharm Des 2007;13:119-126.

Sharma HS, Dey PK: Influence of long-term immobilization stress on regional blood-brain barrier permeability, cerebral blood flow and 5-HT level in conscious normotensive young rats. J Neurol Sci 1986a;72:61-76

-Sharma HS, Dey PK: Probable involvement of 5-hydroxytryptamine in increased permeability of blood-brain barrier under heat stress in young rats. Neuropharmacology 1986b;25:161-167.
Triggs E, Charles B: Pharmacokinetics and therapeutic drug monitoring of gentamicin in the elderly. Clin Pharmacokinet 1999;37: 331-341.

Turker MS, Gage BM, Rose JA, Elroy D, Ponomareva ON, Stambrook PJ, Tischfield JA: A novel signature mutation for oxidative damage resembles a mutational pattern found commonly in human cancers. Cancer Res 1999;59:1837-1839.

Vass Z, Steyger PS, Hordichok AJ, Trune DR, Jancso G, Nuttall AL: Capsaicin stimulation of the cochlea and electric stimulation of the trigeminal ganglion mediate vascular permeability in cochlear and vertebro-basilar arteries: a potential cause of inner ear dysfunction in headache. Neuroscience 2001; 103:189-201.

Vogelzang NJ: Nephrotoxicity from chemotherapy: prevention and management. Oncology (Williston Park) 1991;5:97-102, 105, discussion 105, 109-111.

Walther A, Yilmaz N, Schmidt W, Bach A, Gebhard MM, Martin E, Schmidt H: Methysergide attenuates leukocyte-independent plasma extravasation during endotoxemia. J Crit Care 2001;16:121-126.

Wang Q, Steyger PS: Trafficking of systemic fluorescent gentamicin into the cochlea and hair cells. J Assoc Res Otolaryngol 2009;10: 205-219. 